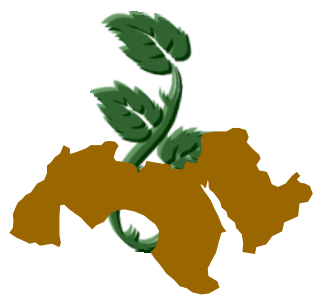

Arab Univ.

J. Agric. Sci., Ain Shams Univ.,

Cairo, 16(2), 255-263, 2008

\title{
INDUCTION OF SOMATIC EMBRYOS AND IMPROVEMENT OF EMBRYOGENIC CALLUS BY TWO TYPES OF SILVER ON DATE PALM (PHOENIX DACTYLEFERA L.)
}

\author{
Rehab A. Sidky ${ }^{1}$ and Aisha M. Abd El- Kawy ${ }^{2}$ \\ 1- Central Laboratory of Date Palm Research and Development, Horticulture Research \\ Institute, ARC, Giza, Egypt. (E-Mail: sidky1234rehab@hotmail.com) \\ 2- Faculty of Science (Girls Branch), Al-Azhar University, Nasr City, Cairo
}

Keywords: Somatic embryos, Silver type, Date palm, Proliferation

\section{ABSTRACT}

The response of embryogenic callus of date palm cvs. (Pertomuda and Skooty) was tested on media containing two types of silver (STS and Ag$\mathrm{NO}_{3}$ ) alone or combined with $0.25 \& 0.5 \mathrm{mg} / \mathrm{l} 2 \mathrm{ip}$. Addition of STS onto callus induction medium significantly enhanced embryogenic callus production (both growth and induction). $\mathrm{AgNO}_{3}$ as a heavy metal ion made a stress treatment on callus to proliferation embryos than STS, this proliferation was increased at a low concentration of $\mathrm{AgNO}_{3}$, but in the presence of 2ip gave the opposite trend, the embryos increased at $4 \mathrm{mg} / \mathrm{l}$ or $6 \mathrm{mg} / \mathrm{l} \mathrm{AgNO}_{3}+0.5$ $\mathrm{mg} / \mathrm{l}$ 2ip and proceeded normally embryos for both Pertomuda and Skooty date palm.

Abbreviations: STS = Silver thiosulphate; $\mathrm{EC}=$ embryogenic callus; NAA $=\alpha$-naphthaleneacetic acid and 2ip = N6-2-isopentenyladenine.

\section{INTRODUCTION}

The induction and regeneration of somatic embryos are very sensitive to culture conditions such as the composition of the medium, the physical environment of the medium, the culture, the genotype and the explants source (Fuentes et al 2000). The environment of ethylene in plant tissue (growth and differentiation) had been widely investigated. Application of ethylene precursors and/or inhibitors has shown that ethylene may often have divers effects on similar tissue culture systems. Although it has been reported that ethylene may promote callus growth (Songstad et al 1991), it generally appears to inhibit somatic embryogenesis and shoot regeneration (Biddington, 1992). Silver nitrate $\left(\mathrm{AgNO}_{3}\right)$, is a potent inhibitor of ethylene action (Beyer, 1976), stimulated somatic embryo development in carrot (Roustan et al 1994).

The most effective silver type is STS (silver thiosulphate) as 1.8 or 1.4 complex of silver nitrate and sodium thiosulphate available as Argylene (1 $\mathrm{g} / \mathrm{l}=0.2 \mathrm{mM} \mathrm{Ag}^{+}$) (Fjeld and Moe, 1985). The STS complex was used because it has much greater mobility in plant tissue than uncomplexed silver ion (Veen and Van De Geun, 1978). Mollers et al 1992 found that the addition of silver thiosulphate to In Vitro potato shoot propagation at $1.5 \mathrm{mg} / \mathrm{l} \mathrm{led}$ to an increase of leaf material. Also, Le (1990) indicated that, the addition of silver thiosulphate to the culture medium improved the explants growth of potato crs.

Besides functioning as an ethylene-action inhibitor, $\mathrm{AgNO}_{3}$ may serve as a stress agent. The successful use of heavy metal ions to induce somatic embryo formation on the surface of carrot seedlings as they act as a stress treatment (Kamada et al 1989, Kiyosue et al 1990). Since stress induces endogenous ABA accumulation (Walker-Simmons and Sesing, 1990, Hauser et al 1992), $\mathrm{Ag}^{+}$being a metallic ion may also promote somatic embryo production via an increase in the endogenous ABA levels.

In date palm (Phoenix dactylifera L.) callus proliferation that normally occurs prior to redifferentiation upon callus transfer to hormone-free regeneration medium, as well as subsequent somatic embryogenesis, were shown to be stimulated by 
$\mathrm{AgNO}_{3}$ added to the regeneration medium in $\mathrm{CV}$. Barhee (Al-Khayri and Al-Bahrany, 2001).

The objectives of the present study were to test the effect of two types of silver on enhancing the production of embryogenic callus in two date palm cvs. And to induce the highest number of somatic embryos.

\section{MATERIALS AND METHODS}

\section{1- Establishment of callus induction}

Shoot tips of date palm (Phoenix dactylefera L.) pertomuda and skooty cvs. were excised and cultured on MS medium (Murashige and Skoog, 1962) supplemented with (per liter) 170mg $\mathrm{NaH}_{2} \mathrm{PO}_{4}, 100$ mg Myo-Inositol, 200mg glutamine, $2 \mathrm{mg}$ glycine, $1 \mathrm{mg}$ biotin, $1 \mathrm{mg}$ thiamine- $\mathrm{HCl}, 1 \mathrm{mg}$ nicotinic acid, $1 \mathrm{mg}$ pyridoxine- $\mathrm{HCl}, 1 \mathrm{mg}$ calcium pantothenate, $30 \mathrm{~g}$ sucrose, $7 \mathrm{~g}$ agar (phytochnology), 100mg 2,4-dichlorophenoxyacetic acid (2,4-D), $3 \mathrm{mg}$ 2-isopentenyladenine (2ip) and $3 \mathrm{~g}$ activated charcoal. These cultures were maintained in darkness at $27 \pm 2^{\circ} \mathrm{C}$ for 6 months. The resultant callus was transferred to callus proliferation medium that contained MS salts augmented with $10 \mathrm{mg} / \mathrm{l}$ 2,4-D and $1.5 \mathrm{~g} / \mathrm{l}$ activated charcoal for 2 months in darkness at $27 \pm 2^{\circ} \mathrm{C}$ for embryogenic callus (EC) formation. Media were adjusted to $\mathrm{pH} 5.7$ and autoclaved for $15 \mathrm{~min}$ at $121^{\circ} \mathrm{C}$ and $1.1 \mathrm{Kg} / \mathrm{cm}^{-2}$.

\section{2- Influence of silver type alone and combined with 2ip.}

To evaluate the type of silver alone or combined with 2ip on maximum embryogenic callus (EC) fresh weight. The explants was cultured on nutrient medium supplemented with different concentration of silver thiosulphate (STS) or $\mathrm{AgNO}_{3}$ at 2, 4, 6 $\mathrm{mg} / \mathrm{l}$ and combined with 0.25 or $0.5 \mathrm{mg} / \mathrm{l} 2 \mathrm{ip}$. Each small jar $\left(150 \mathrm{~cm}^{3}\right)$ was inoculated with $0.30 \mathrm{em}$ bryogenic callus. The cultures were kept in darkness at $25 \pm 2^{\circ} \mathrm{C}$ after 2 months the EC fresh weight was measured which transferred every 4 weeks to new culture (two subcultures).

After that, EC was transferred to MS medium supplemented with $0.1 \mathrm{mg} / \mathrm{l}$ Naphthaleneacetic acid (NAA), $30 \mathrm{~g} / \mathrm{l}$ sucrose, $7 \mathrm{~g} / \mathrm{l}$ agar, $1 \mathrm{mg} / \mathrm{l}$ thia$\mathrm{min}, 1 \mathrm{mg} / \mathrm{l}$ Nicotinic, $1 \mathrm{mg} / \mathrm{l}$ Pyridoxin. $\mathrm{HCl}, 1 \mathrm{mg} / \mathrm{l}$ Biotin and the same concentrations of silver (STS or $\mathrm{AgNO}_{3}$ ) and combined with 0.25 and $0.5 \mathrm{mg} / \mathrm{l}$ 2ip to induce somatic embryos. Cultures were maintained at $25 \pm 2^{\circ} \mathrm{C}$ and $16 \mathrm{~h}$ photoperiod. The number of embryos per culture was counted after two subcultures at 6 weeks intervals.

\section{3- Statistics}

Nine jars were used for each tested concentration containing ( $0.3 \mathrm{~g}$ callus). Factorial Randomized Complete Black Design was used and data were subjected to analysis of variance separation of means among treatments was determined using LSD test at $5 \%$ according to Steel and Torrie (1980).

\section{4- RESULTS}

\subsection{The effect of silver concentration on callus fresh weight and number of somatic em- bryos.}

\subsection{1. cv. Pertomuda}

Callus growth, expressed in fresh weight of cv. Pertomuda was significantly increased in response to adding of STS or $\mathrm{AgNO}_{3}$ to the callus medium (Table 1). STS produced the highest mean weight of callus (0.99 g) compared with $\mathrm{AgNO}_{3}(0.29 \mathrm{~g})$. Further increase of STS stimulated gradual increase in callus fresh weight, reaching the maximum at $6.0 \mathrm{mg} / \mathrm{l} \mathrm{STS}$.

Silver increased embryo production at low concentration after light exposure (Table 1). $\mathrm{AgNO}_{3}$ was more effective than STS to induce embryos, addition of $\mathrm{AgNO}_{3}$ to nutrient medium gave 7.44 embryos/cultures. The highest number of embryos was obtained at 2.0 or $4.0 \mathrm{mg} / \mathrm{AgNO}$ or STS (7.49 \& 5.49) without significant differences between them, but the higher concentrations of silver, caused a reduction in embryo number.

\subsection{2. cv. Skooty}

The effect of adding silver to callus induction medium on culture of date palm cv. Skooty was shown in Table (2). The presence of silver showed remarkable effect for callus growth. The highest mean of callus fresh weight was observed from STS silver type, it increased significantly callus fresh weight $(1.32 \mathrm{~g})$ than $\mathrm{AgNO}_{3}(0.50 \mathrm{~g})$. There were no significant differences among the three silver concentrations on callus fresh weight, in this regard, $6.0 \mathrm{mg} / \mathrm{S} \mathrm{STS}$ or $\mathrm{AgNO}_{3}$ gave the maximum weight of callus.

Addition of both STS or $\mathrm{AgNO}_{3}$ to nutrient medium was effective to induce somatic embryos and did not cause an inhibition of embryos develop- 
ment, $\mathrm{AgNO}_{3}$ induced the highest number of somatic embryos culture (5.77) in the $16 \mathrm{~h}$ light. 
Table 1. Induction of somatic embryos by two silver types of date palm cv. Pertomuda

\begin{tabular}{|c|c|c|c|c|c|c|}
\hline \multirow{2}{*}{$\begin{array}{c}\text { Conc. of } \\
\text { Silver } \\
(\mathbf{m g} / \mathbf{l})\end{array}$} & \multicolumn{3}{|c|}{ Callus fresh weight (g) } & \multicolumn{4}{c|}{ No. of embryos } \\
\cline { 2 - 7 } & STS & AgNO $_{3}$ & Mean (B) & STS & AgNO $_{3}$ & Mean (B) \\
\hline 2.0 & 0.86 & 0.26 & 0.56 & 4.33 & 10.66 & 7.49 \\
4.0 & 0.86 & 0.30 & 0.58 & 3.33 & 7.66 & 5.49 \\
6.0 & 1.26 & 0.33 & 0.79 & 3.33 & 4.00 & 3.66 \\
\hline Mean (A) & 0.99 & 0.29 & & 3.66 & 7.44 & \\
\hline
\end{tabular}

LS D at 0.05

$\begin{array}{lll}A & 0.17 & 2.21 \\ B & N S & 2.71 \\ A B & N S & N S\end{array}$

Table 2. Induction of somatic embryos by two silver types of date palm cv. Skooty

\begin{tabular}{|c|c|c|c|c|c|c|}
\hline \multirow{2}{*}{$\begin{array}{c}\text { Conc. of } \\
\text { Silver } \\
\text { (mg/l) }\end{array}$} & \multicolumn{3}{|c|}{ Callus fresh weight (g) } & \multicolumn{3}{c|}{ No. of embryo } \\
\cline { 2 - 7 } & STS & AgNO $_{3}$ & Mean (B) & STS & AgNO $_{3}$ & Mean (B) \\
\hline 2.0 & 1.4 & 0.56 & 0.98 & 5.00 & 8.00 & 6.50 \\
4.0 & 1.06 & 0.46 & 0.76 & 3.66 & 5.66 & 4.66 \\
6.0 & 1.50 & 0.50 & 1.00 & 3.66 & 3.66 & 3.66 \\
\hline Mean (A) & 1.32 & 0.50 & & 4.10 & 5.77 & \\
\hline
\end{tabular}

\section{S D at 0.05}

$$
\text { A }
$$$$
\text { B }
$$

$A B$

NS

NS
1.11
1.36
NS

The minimum silver concentration induced the highest significant embryo number (6.50) while, the maximum concentration produced the lowest number.

Although, silver had a pronounced influence on the process of somatic embryogenesis, the germination of the resultant somatic embryos and their development into plantlet (data untabulated).

\section{The effect of silver type combination with} 2ip.

\subsection{Callus fresh weight of cv. Pertomuda}

Results in Table (3) show the effect of silver type in the presence of 2ip on callus induction medium.
The callus fresh weight was greater with STS $(0.76 \mathrm{~g})$ than $\mathrm{AgNO}_{3}(0.20 \mathrm{~g})$, the two tested 2ip concentrations enhanced callus fresh weight.

\subsection{Number of embryos of cv. Pertomuda}

Differences were observed between the two types of silver on number of embryos Table (3). $\mathrm{AgNO}_{3}$ had the highest mean number of embryos (2.22), while STS, only showed lower number (1.49) embryos. Addition of 2ip with silver enhanced the formation of somatic embryos of date palm, $0.5 \mathrm{mg} / \mathrm{l}$ 2ip gave the highest number of embryos. $\mathrm{AgNO}_{3}$ at $6 \mathrm{mg} / \mathrm{l}$ combined with $0.5 \mathrm{mg} / \mathrm{l}$ 2ip increased embryo induction and the germination proceeded normally. 
Table 3. Effect of silver type and 2ip on date palm cv. Pertomuda

\begin{tabular}{|c|c|c|c|c|c|c|c|c|}
\hline $\begin{array}{l}\text { Type of silver } \\
\text { (A) }\end{array}$ & $\begin{array}{l}\text { Conc. of } \\
\text { silver } \mathrm{mg} / \mathrm{l} \\
\text { (B) }\end{array}$ & $\begin{array}{l}\text { Conc. of } \\
\text { 2ip (mg/l) } \\
\text { (C) }\end{array}$ & \multicolumn{3}{|c|}{$\begin{array}{l}\text { Callus fresh } \\
\text { weight } \\
\text { (g) }\end{array}$} & \multicolumn{3}{|c|}{ No. of embryos } \\
\hline \multirow{6}{*}{$\stackrel{\infty}{\omega}$} & \multirow[t]{2}{*}{2} & 0.25 & \multicolumn{3}{|c|}{1.00} & \multicolumn{3}{|c|}{2.00} \\
\hline & & 0.50 & \multicolumn{3}{|c|}{0.66} & \multicolumn{3}{|c|}{1.66} \\
\hline & 4 & 0.25 & \multicolumn{3}{|c|}{0.90} & \multicolumn{3}{|c|}{3.00} \\
\hline & & 0.50 & \multicolumn{3}{|c|}{0.56} & \multicolumn{3}{|c|}{1.00} \\
\hline & 6 & 0.25 & \multirow{2}{*}{\multicolumn{3}{|c|}{$\begin{array}{l}0.73 \\
0.73\end{array}$}} & \multirow{2}{*}{\multicolumn{3}{|c|}{$\begin{array}{l}0.66 \\
0.66 \\
\end{array}$}} \\
\hline & & 0.50 & & & & & & \\
\hline Mean A & & & \multicolumn{3}{|c|}{0.76} & \multicolumn{3}{|c|}{1.49} \\
\hline \multirow{6}{*}{$\begin{array}{l}\text { Oొ } \\
\text { Zo } \\
\text { o }\end{array}$} & 2 & 0.25 & \multicolumn{3}{|c|}{0.10} & \multicolumn{3}{|c|}{1.00} \\
\hline & & 0.50 & \multicolumn{3}{|c|}{0.26} & \multicolumn{3}{|c|}{2.66} \\
\hline & 4 & 0.25 & \multirow{2}{*}{\multicolumn{3}{|c|}{$\begin{array}{l}0.16 \\
0.30\end{array}$}} & \multicolumn{3}{|c|}{1.00} \\
\hline & & 0.50 & & & & & 3.33 & \\
\hline & 6 & 0.25 & \multicolumn{3}{|c|}{0.13} & \multicolumn{3}{|c|}{0.00} \\
\hline & & 0.50 & \multicolumn{3}{|c|}{0.26} & \multicolumn{3}{|c|}{5.33} \\
\hline Mean (A) & & & \multicolumn{3}{|c|}{0.20} & \multicolumn{3}{|c|}{2.22} \\
\hline Mean (B) & & & 0.50 & 0.48 & 0.46 & 1.83 & 2.08 & 1.66 \\
\hline Mean (C) & & & 0.50 & & 46 & 1.27 & & 4 \\
\hline
\end{tabular}

LS D at 0.05

$\begin{array}{lcc}A & 0.11 & 0.45 \\ B & N S & N S \\ A B & N S & 0.78 \\ B C & \text { NS } & 0.78 \\ A B C & \text { NS } & 1.10\end{array}$

\subsection{Callus fresh weight of cv. Skooty}

After 8 weeks of culture on nutrient medium supplemented with different concentrations of silver combined with 2ip, different response could be observed in (Table 4 and Fig. 1). STS promotes callus production (both growth and induction). All concentrations of silver (STS, $\mathrm{AgNO}_{3}$ ) enhanced callus fresh weight.

\subsection{Number of embryos of cv. Skooty}

As for the response of silver, addition of both STS or $\mathrm{AgNO}_{3}$ to the nutrient medium was effective to induce somatic embryos and did not cause any inhibition to embryo development (Table 4 and Fig. 1) the optimum concentration increased somatic embryos was $4.0 \mathrm{mg} / \mathrm{l}$ silver. Number of embryos was significantly influenced by the interac- tion between silver and 2ip, the number of resultant embryos was highest on $4 \mathrm{mg} / \mathrm{AgNO}_{3}$ with 0.5 $\mathrm{mg} / \mathrm{l} 2 \mathrm{ip}$, the action of silver was clearly modified by addition of 2ip, because 2ip forms embryos without vitrification.

Generally, the result mentioned that, the maximum silver concentration of STS gave the highest callus fresh weight, while the minimum silver concentration of $\mathrm{AgNO}_{3}$ induced the highest somatic embryos for the two cvs. Silver combined with 2ip increased embryogenesis without vitrification and embryos developed normally.

\section{DISCUSSION}

Silver appears unique among heavy metals as an inhibitor of ethylene action (Beyer, 1976). Transferring embryogenic callus of the different date palm to different concentrations of silver to induce somatic embryos was the aim of this study. 
Table 4. Effect of silver type combination with 2ip of date palm cv. Skooty

\begin{tabular}{|c|c|c|c|c|c|c|c|c|}
\hline $\begin{array}{l}\text { Type of silver } \\
\text { (A) }\end{array}$ & $\begin{array}{c}\text { Conc. of silver } \\
\mathrm{mg} / \mathrm{l}(\mathrm{B})\end{array}$ & $\begin{array}{l}\text { Conc. of 2ip } \\
(\mathrm{mg} / \mathrm{l})(\mathrm{C})\end{array}$ & \multicolumn{3}{|c|}{$\begin{array}{l}\text { Callus fresh weight } \\
(\mathrm{g})\end{array}$} & \multicolumn{3}{|c|}{ No. of embryos } \\
\hline \multirow{6}{*}{$\stackrel{\omega}{\omega}$} & \multirow[t]{2}{*}{2} & 0.25 & \multicolumn{3}{|c|}{1.3} & \multicolumn{3}{|c|}{2.66} \\
\hline & & 0.50 & \multicolumn{3}{|c|}{0.76} & \multicolumn{3}{|c|}{2.00} \\
\hline & 4 & 0.25 & \multicolumn{3}{|c|}{1.03} & \multicolumn{3}{|c|}{3.00} \\
\hline & & 0.50 & \multicolumn{3}{|c|}{0.70} & \multicolumn{3}{|c|}{1.33} \\
\hline & 6 & 0.25 & \multirow{2}{*}{\multicolumn{3}{|c|}{$\begin{array}{c}0.9 \\
0.86\end{array}$}} & \multirow{2}{*}{\multicolumn{3}{|c|}{$\begin{array}{l}0.66 \\
0.66 \\
\end{array}$}} \\
\hline & & 0.50 & & & & & & \\
\hline Mean A & & & \multicolumn{3}{|c|}{0.92} & \multicolumn{3}{|c|}{1.71} \\
\hline \multirow{6}{*}{ ญ̊ } & 2 & 0.25 & \multicolumn{3}{|c|}{0.16} & \multicolumn{3}{|c|}{0.00} \\
\hline & & 0.50 & \multicolumn{3}{|c|}{0.56} & \multicolumn{3}{|c|}{2.33} \\
\hline & 4 & 0.25 & \multirow{2}{*}{\multicolumn{3}{|c|}{$\begin{array}{l}0.33 \\
0.56\end{array}$}} & \multirow{2}{*}{\multicolumn{3}{|c|}{$\begin{array}{l}1.33 \\
3.33\end{array}$}} \\
\hline & & 0.50 & & & & & & \\
\hline & 6 & 0.25 & \multirow{2}{*}{\multicolumn{3}{|c|}{$\begin{array}{l}0.20 \\
0.36\end{array}$}} & \multicolumn{3}{|c|}{0.00} \\
\hline & & 0.50 & & & & & 3.66 & \\
\hline Mean (A) & & & \multicolumn{3}{|c|}{0.36} & \multicolumn{3}{|c|}{1.77} \\
\hline Mean (B) & & & 0.69 & 0.65 & 0.58 & 1.47 & 2.24 & 1.24 \\
\hline Mean (C) & & & \multicolumn{2}{|c|}{0.65} & .63 & \multicolumn{2}{|c|}{1.27} & .21 \\
\hline
\end{tabular}

L. S. D. at 0.05

$\begin{array}{lcc}A & 0.16 & \text { NS } \\ B & \text { NS } & 0.64 \\ A B & \text { NS } & 0.90 \\ B C & \text { NS } & 0.90 \\ A B C & \text { NS } & \text { NS }\end{array}$

The current study observed that, $\mathrm{AgNO}_{3}$ as a heavy metal ion made a stress treatment on callus to proliferate embryos than STS, this proliferation was increased at a low concentrations of $\mathrm{AgNO}_{3}$. Biddington et al 1988 suggests that, $\mathrm{AgNO}_{3}$ promotes embryogenesis in Brussels sprouts by blocking the inhibitory effect of endogenous ethylene on embryo production. It is also possible that, stimulation by $\mathrm{AgNO}_{3}$ in white spruce is gradually eclipsed by higher concentrations of exogenous $A B A$ in the maturation medium combined with the results of $A B A$ analysis, demonstrate that $\mathrm{AgNO}_{3}$ may affect embryo maturation mainly by influencing endogenous $\mathrm{ABA}$ levels (Kong and Yeung, 1995). In carrot, $\mathrm{AgNO}_{3}$ can stimulate somatic embryo formation even in the presence of an exogenous ethylene source, ethephon (Roustan et al 1990). Kamada et al (1993) found that, gene expression of a protein (ECP31) directly related to embryogenic competence, was commonly observed in some stress treatments which could induce somatic embryogenesis in carrot. The gene expression of ECP 31 was also controlled by abscisic acid.

Silver at higher levels caused a reduction on number of somatic embryos. This result agree with Biddington et al (1988) and Al-Khayri and AlBahrany (2004). Conversely, Hatanaka et al (1995) mentioned that addition of $\mathrm{AgNO}_{3}$ (5-50 $\mu \mathrm{M})$ or $\mathrm{CoCl} 2(10-50 \mu \mathrm{M})$ throughout all culture stages inhibited the formation of somatic embryos in leaf explants of Coffea canephora.

The STS complex was used because it has much greater mobility in plant tissue than uncomplexed silver ion (Veen and Van De Geun, 1978). In this study, adding silver to callus induction medium enhanced the growth of callus, STS at $6 \mathrm{mg} / \mathrm{l}$ was the most effective concentration for increasing 
Fig. 1. Effect of different concentration of $\mathrm{AgNO}_{3}$ combined with 2ip to induce somatic embryos of date palm cv. Skooty 
callus fresh weight, however, STS was producing the highest weight of callus for both cvs.. Similarly, the most effective silver type is $\mathrm{Ag}^{+}$as (STS) a $1: 8$ or 1:4 complex of silver nitrate and sodium thiosulphate available as argylene $\left(1 \mathrm{~g} / \mathrm{l}=0.2 \mathrm{mM} \mathrm{Ag}^{+}\right)$ (Fjeld and Moe, 1985). Balletti et al (1994) suggested that the addition of silver thiosulphate (STS) to the culture medium improved the growth of potato explant crs..

In date palm, the number of embryos increased in response to increasing silver nitrate concentration in the absence of 2ip. In the presence of 2ip, the number of resultant embryos was high on 25 micro $\mathrm{M} \mathrm{AgNO}_{3}$ in the combination of 0.5 micro $\mathrm{M}$ 2ip, callus growth gradually increased as the Ag$\mathrm{NO}_{3}$ concentration increased (Al-Khayri and AlBahrany, 2001; 2004). Callus initiation rate was improved when immature embryos were cultured on a modified Murashige \& Skoog medium containing various silver nitrate concentrations (Vain et al 1989).

In contrast to our results, Tsao and Reed, 2002 reported that silver nitrate significantly reduced callus growth in Rubus spp. a $59 \mu \mathrm{M}$ and in Saccharum spp. at 29-118 $\mu \mathrm{M}$ (Taylor et al 1994).

\section{REFERENCES}

Al-Khayri, J.M. and A.M. Al-Bahrany (2001). Silver nitrate and 2-isopentyladenine promote somatic embryogenesis in date palm (Phoenix dactylifera L.) Scientia Horticulture 89: 291-298.

Al-Khayri, J.M. and A.M. Al-Bahrany (2004). Genotype-dependant In Vitro response of date palm (Phoenix dactylifera L.) cultivars to silver nitrate. Scientia Horticulture 99: 153-162.

Balletti, P.; S. Lanteri; S. Lotito; F. Saracco; L. Quagllotti and P. Ballett (1994). Production of potato micro tubers through In Vitro culture. Acta Horticulture 362: 141-148.

Beyer, E.M. (1976). A potent inhibitor of ethylene action in plants. Plant Physiol. 58: 268-271.

Biddington, N.L. (1992). The influence of ethylene in plant tissue culture. Plant Growth Regul. 11: 173-187.

Biddington, N.L.; R.A. Sutherland and H.T. Robinson (1988). Silver nitrate increases embryo production in Anther culture of Brussels sprouts. Annals of Botany 62: 181-185.

Fjeld, T. and R. Moe (1985). Compounds to increase shelf life, specially silver thiosulfate (STS). Garther Tidende 49; 1380-1583.

Fuentes, S.R.L.; M.B.P. Calheiros; J. ManettiFilho and L.G.E. Vieira (2000). The effect of silver nitrate and different carbohydrate sources on somatic embryogenesis in Coffea canephora. Plant Cell Tiss. Org. Cult. 60: 5-13.

Hatanaka, T.; E. Sawabe; T. Azuma; N. Uchida and T. Yasuda (1995). The role of ethylene in somatic embryogenesis from leaf discs of Coffea canephora. Plant Sci. 107: 199-204.

Hauser, C.; J. Jung and K. Grossmann (1992). Changes in abscisic acid levels of heterotrophic cell suspension cultures caused by the plant growth retardant BAS III and possible physiological consequences. In Progress in: Plant Growth Regulation (Karssen, C.M.; L.C. Van Loon and D. Vrengdenhil, eds). pp. 173-179. Kluwer Academic publishers. Dordrecht. ISBN 0-7923-1617-7.

Kamada, H.; K. Kobayashi; T. Kiyosue and H. Harada (1989). Stress induced somatic embryogenesis in carrot and its application to synthetic seed production. In Vitro Cell Dev. Biol. 25: 11631169.

Kamada, H.; K. Ishikawa; H. Saga and H. Harada (1993). Introduction of somatic embryogenesis in carrot by somotic stress. Plant Tissue Culture Letters 10: 38-44.

Kiyosue, T.; K. Takano; H. Kamada and H. Harada (1990). Induction of somatic embryogenesis in carrot by heavy metal ions. Can. J. Bot. 68: 2301-2303.

Kong, L. and E.C. Yeung (1995). Effect of silver nitrate and polyethylene glycol on white spruce (Picea glauca) somatic embryo development: enhancing cotyledonary embryo formation and endogenous ABA content. Physiol. Plant. 93: 298304.

Le, C. (1990). Effect of silver thiosulphate on growth of potato cultured In Vitro. Revue-Suifse-D, Agriculture 28(1): 43-45.

Mollers, C.; S. Zhang and G. Wenz (1992). The influence of silver thiosulfate on potato protoplast cultures. Plant Breeding 108(1): 12-18.

Murashige, T. and F. Skoog (1962). A revised medium for rapid growth and bioassay with tobacco tissue cultures. Physiol. Plant. 15: 473-497.

Roustan, J.P.; A. Latche and J. Fallot (1990). Control of carrot somatic embryogenesis by $\mathrm{Ag}$ $\mathrm{NO}_{3}$, an inhibitor of ethylene action: effect on arginine decarboxylase activity. Plant Sci. 67: 89-95.

Roustan, J.P.; A. Latche and J. Fallot (1994). Role of ethylene on induction and expression of carrot somatic embryogenesis: relationship with polyamine metabolism. Plant Sci. 103: 223229.

Songstad, D.D.; C.L. Armstrong and W.L. Petersen (1991). $\mathrm{AgNO}_{3}$ increases type II callus pro- 
duction from immature embryos of maize inbred 873 and its derivatives. Plant Cell Rep. 9: 699702.

Steel, R.G. and J.T.H. Torrie (1980). Principles and Procedures of Statistics, a Biochemical Approach, pp. 469-517. McGraw-Hill Book Company, New York.

Taylor, P.W.J.; H.L. Ko; T.A. fraser; N. Masel; S.W. Adkins (1994). Effect of silver nitrate on sugar cane cell suspension growth, protoplast isolation, ethylene production and shoot regeneration from cell suspension culture. J. Exp. Bot. 45:11631168.
Tsao, C.W.V. and B.M. Reed (2002). Gelling agent, silver nitrate and sequestrene iron influence adventitious shoot and callus formation from Rubus leaves In Vitro. Dev. Biol. Plant 38: 29-32. Vain, P.; H. Yean and P. Flament (1989). Enhancement of production and regeneration of embryogenic type IT callus in Zea mays L. by $\mathrm{AgNO}_{3}$. Plant Cell Tissue and Organ Culture 18: 143151.

Veen, I.I. and Van De Geun (1978). Mobility and ionic form of silver as related to longevity of cut canations. Planta, 140: 62-96.

Walker-Simmons, M. and J. Sesing (1990). Temperature effects on embryonic abscisic acid levels during development of wheat grain dormancy. J. Plant Growth Regul. 9: 51-56. 